University of Nebraska - Lincoln

DigitalCommons@University of Nebraska - Lincoln

June 1994

\title{
Women and the Great Retrenchment: The Political Economy of Gender in the 1980s
}

Ann Mari May

University of Nebraska - Lincoln, amay1@UNL.edu

Follow this and additional works at: https://digitalcommons.unl.edu/cbafacpub

Part of the Business Commons

May, Ann Mari, "Women and the Great Retrenchment: The Political Economy of Gender in the 1980s" (1994). College of Business Faculty Publications. 26.

https://digitalcommons.unl.edu/cbafacpub/26

This Article is brought to you for free and open access by the Business, College of at DigitalCommons@University of Nebraska - Lincoln. It has been accepted for inclusion in College of Business Faculty Publications by an authorized administrator of DigitalCommons@University of Nebraska - Lincoln. 


\title{
Women and the Great Retrenchment: The Political Economy of Gender in the 1980 s
}

\author{
Ann Mari May \\ and \\ Kurt Stephenson
}

Policy analysts and scholars are only now beginning the serious task of sifting through the debris of the 1980s to chronicle the impacts of policy changes and to evaluate the policies as well as the policymakers. The 1980 s will no doubt be remembered as having produced the worst recession since the Great Depression and perhaps, more generally, as a period of economic retrenchment [Dugger 1992]. While many segments of society were affected by the restructuring inherent in Reaganomics, the impact on women merits special attention, particularly in light of demographic changes in voting behavior. It has long been understood that discernable differences exist between women and men on issues, party identification, and candidate selection. Women tend to favor less military spending and more government spending on social services, to more often identify with the Democratic party, and to vote for Democratic candidates over Republican candidates [Matlack 1987; Shapiro and Mahajan 1986; Zipp and Plutzer 1985]. In the 1980 s, however, women's participation rates exceeded those of men for the first time in U.S. history. Women

The authors are Associate Professor of Economics, University of Nebraska-Lincoln, and graduate student in Economics at the University of Nebraska-Lincoln, respectively. This paper was presented at the annual meeting of the Association for Evolutionary Economics, Boston, Massachusetts, January 3-5, 1994. 
emerged from the 1980 s as a significant, although certainly nonmonolithic, electoral force.

At the same time that women have become more prominent electorally, there has been an increased recognition of the political nature of women's economic status [Nelson 1984]. Following the expansion of the late $1960 \mathrm{~s}$ and $1970 \mathrm{~s}$, increasing numbers of women have been employed in government jobs associated with the social safety net. Moreover, the feminization of poverty has resulted in an increased attachment to the state at the very time that much of mainstream political discourse has reflected a distinctly anti-statist perspective. Finally, working women in all socioeconomic groups have become increasingly aware of the political nature of their economic status because of the protection offered to women through Title VII of the Civil Rights Act and the accompanying executive orders pertaining to sexual discrimination. The 1980s stand out, then, as a period when women's attachment to the state was increasingly at odds with the dominant political rhetoric.

\section{The 19808 and Women's Attachment to the State}

In 1982 , as the unemployment rate reached its highest level since the early 1940s, President Ronald Reagan responded with the following assessment of the unemployment statistics. According to Reagan, "Part of the unemployment is not as much recession as it is the great increase in the people going into the job market and, ladies, I'm not picking on anyone, but because of the increase in women who are working today ..." [Public Papers of the Presidents 1983, 483].

Although it is more than a stretch to blame the $1981-82$ recession on women's entrance into the paid labor force, it is indeed true that women had entered the labor force at an accelerated pace during the $1970 \mathrm{~s}$. The female participation rate was 42.7 percent in 1969; by 1982, the rate stood at 52.6 percent [Economic Report of the President 1992, 337]. Moreover, female participation rates continued to increase throughout the 1980 s, albeit at a slower pace.

While increasing numbers of women participated in the paid labor force, the civilian unemployment rate for women fell below that of men for the first time in the postwar era [Economic Report of the President 1992, 341]. In addition, the pay gap between men 
and women, which was relatively constant throughout the $1960 \mathrm{~s}$ and $1970 \mathrm{~s}$, began to narrow in the 1980s. Where women earned 60 percent of what men earned in 1980, they earned 72 percent by 1990 [Economic Report of the President 1992, 101].

On its face then, conditions for women in the labor market seem to have improved in the $1980 \mathrm{~s}$, and women who, according to poll data throughout the 1980 s, were apprehensive about Reagan, might appear to have been well served by the "good old time religion of the market" ritualistically espoused by "the Gipper." In reality, however, the policies of the Reagan years had enormous but not always happy consequences for women. The gendered assumptions embedded in Reaganomics were part of an attempt to increase women's dependence on the patriarchal family, while the policies often worked to increase women's dependence on the state.

If there was a unifying theme to Reaganomics, and there was, it was the theme of limited government. In campaign speeches and later in the Economic Report of the President, Reagan consistently emphasized the need to cut the rate of growth in federal spending while increasing defense expenditures [Economic Report of the President 1982, 23]. However, despite his emphasis on limiting the growth of government, Reagan was not successful in cutting government spending. Instead, the character of government spending changed considerably in the 1980s.

In the year before Reagan took office, defense spending accounted for 22.7 percent of total federal outlays. In 1988, when Reagan left office, this figure had risen to 27.3 percent. In contrast, the percentage of federal outlays going to social services and income security both decreased by 2.4 percent over the same period [Economic Report of the President 1989, 398-99]. This restructuring of federal government spending had significant effects on women both in terms of employment opportunities as well as available services.

In $1970,33.1$ percent of full-time federal white-collar civilian employees were women. By 1980, that figure had risen to 38.6 percent and by 1987, 48.2 percent [Statistical Abstract of the United States 1992, 330]. The average annual increase in female federal white-collar workers was 1.7 percent per year in the 1970s and 3.6 percent per year in the $1980-1987$ period.

Not surprisingly, perhaps, women's federal employment tends to be concentrated in the lowest pay grades. For example, while 
72.2 percent of those employed in the lowest pay grade were women in 1970 , only 1.4 percent of those employed in the highest pay grade were women. Most of the growth in women's employment in the various pay grades, both in the $1970 \mathrm{~s}$ and in the 1980 s, occurred in the higher pay grades in which women are vastly underrepresented. However, while growth rates in employment for women in the 1980 s continued to be in higher pay grades, the rate of growth declined in the 1980s. For example, the annual average rate of growth of employment of white-collar women workers in the highest pay grade fell from 21.4 percent in the 1970s to 8.1 percent from 1980 to 1987 [Statistical Abstracts of the United States 1992, 330].

There is good reason to believe that Reagan's restructuring of federal outlays dampened the improvement in women's position in federal employment. In 1989, the EEOC ranked the federal government agencies with the best hiring and payment records for women and minorities. The 10 top agencies are listed in Table 1 along with the total number of employees for each agency in 1982 and 1988.

The data in Table 1 reveal that the agencies with the best records for hiring women and pay equity were also the ones most likely to feel the pain of Reagan's budgetary axe. Seven of the 10 agencies lost employees between 1982 and 1988. In the EEOC's list

Table 1. Equal Employment Opportunity Commission Composite Ranking of Agencies with the Best Record for Women and Minority Employment/Pay

\begin{tabular}{lcrr}
\hline \hline & $\begin{array}{c}\text { \% Female } \\
\text { Employment } \\
\text { in 1988 }\end{array}$ & $\begin{array}{c}\text { \# of } \\
\text { Employees } \\
\text { in 1982 }\end{array}$ & $\begin{array}{r}\text { \# of } \\
\text { Employees } \\
\text { in 1988 }\end{array}$ \\
\hline 1. Housing and Urban Dev. & $56 \%$ & 13,708 & 12,625 \\
2. EEOC & $64 \%$ & 2,934 & 3,059 \\
3. Education & $58 \%$ & 4,985 & 4,173 \\
4. Soldiers and Airman's Home & $58 \%$ & 672 & 803 \\
5. Health and Human Services & $67 \%$ & 130,646 & 111,143 \\
6. Veteran Affairs & $57 \%$ & 208,542 & 207,446 \\
7. Treasury & $55 \%$ & 109,418 & 138,760 \\
8. Small Business Admin. & $48 \%$ & 4,087 & 3,683 \\
9. Office of Personnel Mang. & $61 \%$ & 5,894 & 5,838 \\
10. General Service Admin. & $40 \%$ & 28,192 & 18,549 \\
\hline
\end{tabular}

Source: Equal Employment Opportunity Commission, 1991. 
of hospitable agencies, only the Department of the Treasury significantly increased its number of employees. At the same time, the Department of Defense, with the greatest number of employees $(911,084$ in 1988), as well as the beneficiary of relative growth in federal spending, did not employ large numbers of women. In 1988, only 34.5 percent of defense department employees were women, almost half the rate of women employed by Health and Human Services [Equal Employment Opportunity Commission 1991, 35].

Not only did the restructuring of federal spending affect employment in the governmental sector, but there are private sector impacts as well. A recent study by John D. Abell, examined the effect of changes in defense spending and nondefense spending on unemployment for white and black women and white and black men for 1974-1980 and 1981-1987 [Abell 1992]. According to Abell, increases in defense spending in the 1970s, as well as the $1980 \mathrm{~s}$, resulted in an increase in unemployment overall. ${ }^{1}$ However, the impact was not distributed equally among all workers. In the 1970 s, increases in defense expenditures resulted in only small increases in unemployment for white women, whereas white males experienced larger increases in unemployment. In contrast, an increase in nondefense expenditures in the 1970 s resulted in lower unemployment rates for black females, black males, and white females but an increase in unemployment for white males.

Abell's study indicates that increases in defense spending in the 1980 s shifted sectoral employment so as to actually increase overall unemployment. However, whereas white males were hurt the most from increases in defense expenditure in the 1970s, they tended to be hurt least in the $1980 \mathrm{~s}$. According to Abell, the results suggest "that the detrimental effects fall most heavily upon those, namely women and minorities, who are less than proportionately represented in defense related occupations" [Abell $1992,37]$.

At the same time, increases in nondefense spending had a larger impact on reducing unemployment in the 1980s than in the 1970 s. Moreover, whereas white males were the only category experiencing an increase in unemployment with increases in nondefense spending in the $1970 \mathrm{~s}$, white males were the primary beneficiaries of such increases in the 1980s [Abell 1992, 38]. While the changes in the impact of an increase in defense expenditures 
on white males may indeed represent the influence of a continued shift in defense expenditures toward high technology and capitalintensive production, yet to be explained is the new positive impact of increases in nondefense expenditures on white males in the 1980 s.

The effects of the restructuring of federal spending were felt even more directly through decreased support for social programs in the $1980 \mathrm{~s}$. Because women represent an increased percentage of the poor, these cuts had a disproportionate impact on women. Women constitute more than half of the users of most major social programs: 64.8 percent of medicare users, 61.6 percent of social security, 70 percent of housing, 56.7 percent of food stamps, and most significantly, 81.1 percent of Aid to Families with Dependent Children [Nelson 1984, 222]. Interestingly enough, the program that suffered the largest decline in spending from 1980 to 1988 was also the program that had the highest percentage of women as clients or recipients, AFDC. At a time when increasing numbers of women were living in poverty with a necessarily increased attachment to the state, Reagan was not only openly critical of such beneficiaries, but actively working to make benefits less available.

Apart from the cuts in spending allocated to the AFDC program (which was reduced 11.2 percent from 1980 to 1988 [Peterson $1991,113])$, some of the most damaging changes in AFDC were initiated in the 1981 Omnibus Budget Reconciliation Act (OBRA). OBRA resulted in 27 specific policy changes that worked to severely limit access to aid, and one of the most punitive changes came in the form of a cap on eligibility. As a result of OBRA, a family with gross income greater than 150 percent of state needs standards could not receive AFDC benefits [Joe and Rogers 1985]. Moreover, even if a family's gross earned income was less than 150 percent of the state needs standard, redefinition of the so-called " $\$ 30$ plus one-third disregard" rule also worked to provide less income to working families. The "\$30 plus one-third disregard," which allowed working families to keep $\$ 30$ of monthly earnings plus a third of the remainder to be excluded from gross earnings when determining AFDC benefits, was altered to apply to net earnings instead, a smaller earnings figure [Joe and Rogers 1985]. Other rules capped the amount that working parents could deduct for work-related childcare expenses, changed the maximum age of child participation from 21 to 18 , and lowered asset eligibility limits from $\$ 2,000$ to $\$ 1,000$, making it increasingly difficult for 
poor working mothers to be eligible for AFDC. And finally, after OBRA, two-earner families could only receive AFDC-up aid if the "principal" household earner was unemployed. Thus, as Dorothy Miller states, this last change was "a way of limiting eligibility for families with unemployed wives and reestablishing the patriarchal standard of men as bread winners" [Miller 1990, 37].

While spending cuts in AFDC were enacted and eligibility requirements stiffened, real monthly benefit levels of the various entitlement programs waned as well. According to Robert Reischauer, total real monthly benefits received from AFDC, food stamps, and medicare declined from $\$ 859$ to $\$ 747$ in 1982 dollars [Reischauer 1989, 15]. Moreover, if a poor family became ineligible for AFDC, medicaid coverage was in most cases terminated. According to one study, an estimated one-third of the Michigan and Georgia working families cut from AFDC rolls were left with no health coverage [Sarri and Russell 1988].

Finally, working women in the United States became increasingly aware of sexual harassment on the job in the 1980s. In a 1989 New York Times poll, women were asked about "the most important problem facing women today." The answer, job discrimination [Dionne 1989, A1]. Public opinion polls throughout the 1980s showed that as many as 94 percent of women complained of unequal pay, and 82 percent of women claimed to have experienced job discrimination [Dionne 1989, A18]. A survey by the Merit Systems Protection Board (1988) reported that 42 percent of female civil servants reported sexual harassment in the two-year period preceding the survey [Havermann 1988, A1].

The Equal Employment Opportunity Commission (EEOC) remains women's primary defense against workplace discrimination, and women do make use of its services. According to the EEOC, the total number of sex discrimination charges filed increased more than 25 percent during the Reagan years [EEOC 1982,1990 ]. However, while the number of sex discrimination charges filed increased, both funding and staffing of the EEOC decreased.

According to Table 2, funding for the EEOC in real terms declined 4.6 percent from 1981 to 1988 with the total budget falling from around $\$ 175$ million to around $\$ 167$ million. Cutbacks in staffing were even more pronounced. Full-time staffing declined by 8.7 percent during the same period. 
Table 2. Funding and the Employment of the Equal Employment Opportunity Commission: 1981-1988

\begin{tabular}{lcc}
\hline \hline & $\begin{array}{c}\text { Total Budget } \\
\text { (1987 dollars) }\end{array}$ & $\begin{array}{c}\text { Staffing/Full- } \\
\text { Time Equivalent }\end{array}$ \\
\hline 1981 & $\$ 175,190,600$ & 3,468 \\
1982 & $\$ 167,814,300$ & 3,166 \\
1983 & $\$ 166,802,700$ & 3,084 \\
1984 & $\$ 167,252,700$ & 3,044 \\
1985 & $\$ 171,147,600$ & 3,097 \\
1986 & $\$ 167,066,700$ & 3,017 \\
1987 & $\$ 169,730,000$ & 2,941 \\
1988 & $\$ 167,201,700$ & 3,168 \\
\hline
\end{tabular}

Source: Equal Employment Opportunity Commission, 1988, 1990.

\section{Conclusion}

Women's income provided a buffer against the secular decline in real wages in the 1980 s, just as women's income provided a buffer against decreases in income in the 1930s. Moreover, just as women's income was portrayed as secondary in the 1930s, the same kinds of gendered assumptions have continued to influence government policy well into the 1980 s.

There is, however, a fundamental incongruence between the demographic realities of the labor market of the 1980s and the promarket ideology of the Reagan years. Despite attempts to increase women's dependence upon the patriarchal family, poor women's attachment to the state is increasing, as reflected in the feminization of poverty. Working women in general have become increasingly attached to the state not only as a source of employment, but also as a mediator of conflicts arising out of the gender transformation of the labor market. Therefore, even if improvements in poverty for women occur, this emerging tension will not go away.

\section{Notes}

1. The empirical results derived in Abell's article may be explained as a result of relative shifts in product demand from one sector to another wherein employment demand is shifting away from a surplus labor sector employing large numbers of low-wage workers 
to a high-technology sector employing few relatively high-wage workers. For an explanation of the impact of shifts in sectoral demand on unemployment, see, for example, Lilien [1982].

\section{References}

Abell, John D. "Defense Spending and Unemployment Rates: An Empirical Analysis Disaggregated by Race and Gender." American Journal of Economics and Sociology 51 (1992): 27. 42.

Dionne, E. J., Jr. "The Struggle for Work and Family Fueling Women's Movement." New York Times, 22 August 1989, p. A1 and A18.

Dugger, William M. "The Great Retrenchment: Pecuniary Gains and Industrial Losses." Journal of Economic Issues 26 (1992): 561-71.

Economic Report of the President 1982. Washington, D.C.: U.S. Government Printing Office, 1982.

Economic Report of the President 1989. Washington, D.C.: U.S. Government Printing Office, 1989.

Economic Report of the President 1992. Washington, D.C.: U.S. Government Printing Office, 1992.

Equal Employment Opportunity Commission. 16th Annual Report, Fiscal Year 1981. Washington, D.C.: U.S. Government Printing Office, 1982.

. 20th Annual Report, Fiscal Year 1985. Washington, D.C.: U.S. Government Printing Office, 1988.

. Combined Annual Report, Fiscal Years 1986, 1987, 1988. Washington, D.C.: U.S. Government Printing Office, 1990.

Annual Report on the Employment of Minorities, Women, and People with Disabilities in the Federal Government. Washington, D.C.: U.S. Government Printing Office, 1991.

Havermann, Judith. "42\% of Female Civil Servants Report Sexual Harassment." Washington Post, 30 June 1988, p. A1.

Joe, Tom, and Cheryl Rogers. By the Few for the Few: The Reagan Welfare Legacy. Lexington, Mass.: Lexington Books, 1985.

Lilien, David M. "Sectoral Shifts and Cyclical Unemployment." Journal of Political Economy 90 (1982): 777-92. 
Matlack, Carol. "Women at the Polls." National Journal 19 (1987): 3208-15.

Miller, Dorothy C. Women and Social Welfare: A Feminist Analysis. New York: Praeger, 1990.

Nelson, Barbara J. "Women's Poverty and Women's Citizenship: Some Political Consequences of Economic Marginality." Signs: Journal of Women in Culture and Society 10 (1984): 209-31.

Peterson, Wallace C. Transfer Spending, Taxes and the American Welfare State. Norwell, Mass.: Kluwer Academic Publishers, 1991.

Public Papers of the Presidents of the United States, Ronald Reagan 1982, Vol. 1. Washington, D.C.: U.S. Government Printing Office, 1983.

Reischauer, Robert D. "The Welfare Reform Legislation: Directions for the Future." In Welfare Policy for the 1990s, edited by Phoebe H. Cottingham and David T. Ellwood. Cambridge, Mass.: Harvard University Press, 1989.

Sarri, Rosemary C., and Carol Crill Russell. "Health and Poverty in Single-Parent Families: The Consequences of Federal Policy Change." In Poverty and Social Welfare in the United States, edited by Donal Tomaskovic-Devey. Boulder, Colo.: Westview Press, 1988.

Shapiro, Robert Y., and Harpreet Mahajan. "Gender Differences in Policy Preferences: A Summary of Trends from the 1960s to the 1980s." Public Opinion Quarterly 50 (1986): 42-61.

Statistical Abstracts of the United States 1992. Washington, D.C.: U.S. Bureau of the Census, 1992.

Zipp, John, and Eric Plutzer. "Gender Differences in Voting for Female Candidates." Public Opinion Quarterly 49 (1985): 179-97. 